\title{
The Size and Incidence of the Losses from Noise Trading
}

\section{Citation}

De Long, J., J. Bradford, Andrei Shleifer, Lawrence H. Summers, and Robert J. Waldmann. 1989. "The Size and Incidence of the Losses from Noise Trading." The Journal of Finance 44 (3) (July): 681-696. Portico. doi:10.1111/j.1540-6261.1989.tb04385.x.

\section{Published Version}

doi:10.1111/j.1540-6261.1989.tb04385.x

\section{Permanent link}

http://nrs.harvard.edu/urn-3:HUL.InstRepos:27693804

\section{Terms of Use}

This article was downloaded from Harvard University's DASH repository, and is made available under the terms and conditions applicable to Other Posted Material, as set forth at http:// nrs.harvard.edu/urn-3:HUL.InstRepos:dash.current.terms-of-use\#LAA

\section{Share Your Story}

The Harvard community has made this article openly available.

Please share how this access benefits you. Submit a story.

Accessibility 
NBER WORKING PAPER SERIES

THE SIZE AND INCIDENCE OF THE LOSSES FROM NOISE TRADING

J . Bradford De Long

Andrei Shleifer

Lawrence H, Summers

Robert J. Waldmann

Working Paper No. 2875

NATIONAL BUREAU OF ECONOMIC RESEARCH

1050 Massachusetts Avenue

Cambridge, MA 02138

March 1989

We would like to thank the Alfred P. Sloan and Russel Sage Foundations for financial support, and Bob Barsky, David Cutler, Ken Froot, Lawrence Katz, Merton Miller, Marco Pagano, and Hans Stoll for helpful comments. This paper is part of NBER's research program in Financial Markets and Monetary Economics. Any opinions expressed are those of the authors not those of the National Bureau of Economic Research. 
NBER Working Paper \#2875

March 1989

THE SIZE AND INCIDENCE OF THE LOSSES FROM NOISE TRÁDING

\section{ABSTRACT}

Recent empirical research has identified a significant amount of volatility in stock prices that cannot be easily explained by changes in fundamentals; one interpretation is that asset prices respond not only to news but also to irrational "noise trading." We assess the welfare effects and incidence of such noise trading using an overlapping-generations model that gives investors short horizons. We find that the additional risk generated by noise trading can reduce the capital stock and consumption of the economy, and we show that part of that cost may be borne by rational investors. We conclude that the welfare costs of noise trading may be large if the magnitude of noise in aggregate stock prices is as large as suggested by some of the recent empirical literature on the excess volatility of the market.

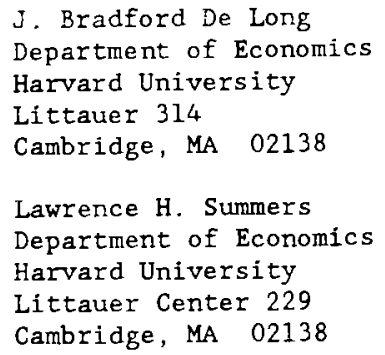

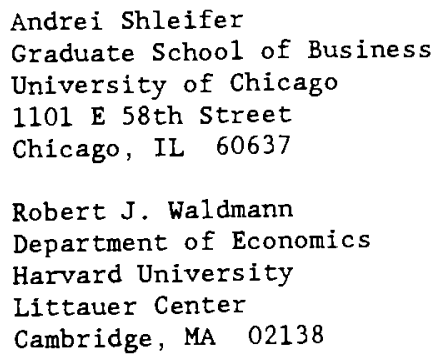




\section{INTRODUCTION}

Recent empirical research has identified a significant amount of volatility in stock prices that cannot be easily explained by changes in fundamentals (Shiller, 1981; Leroy and Porter, 1981; French and Roll, 1986; Cutler, Poterba, and Summers, 1987; Roll, 1984, 1988). One interpretation of these results, which has many adherents among both economists and investors (for example Keynes, 1936; Wojnilower, 1980; Buffett, 1985), is that asset prices respond not only to news but also to irrational demands, or "noise trading" (Kyle, 1985; Black, 1986). According to Keynes (1936), "those who seriously attempt to make any such estimate" of fundamental values "are often so much in the minority that their behavior does not govem the market."

The concern over the possible noisiness of asset prices comes from the belief that noise trading increases the risk of investment. According to Wojnilower (1980): "The freeing of financial markets to pursue their casino instincts heightens the odds of ...crises.... Because, unlike a casino, the financial markets are inextricably linked with the world outside, the real economy pays the price." Similar considerations led Keynes $(1936$, p. 160). to argue that there was something to be said for taking strong steps to reduce short-term noise trading, for "mak[ing] the purchase of an investment permanent and indissoluble, like marriage... For this would force the investor to direct his mind to the long-term prospects and to those only." Since Keynes saw business cycles as largely driven by "fluctuations in the marginal efficiency of investment," in his estimation a reduction in noise trading promised a moderation of the business cycle.

An evaluation of the size and incidence of losses from noise trading requires a formal model of the stock market in which the arguments made by Keynes (1936) and Wojnilower (1981) could have force. In this paper we present one such model. Our model differs from earlier studies of noise trading (Kyle, 1985; Black, 1986; Campbell and Kyle, 1988; and De Long, Shleifer, Summers, and Waldmann, DSSW 1987) in that we explicitly focus on the effect of noise trading on capital formation and so can assess its welfare costs. ${ }^{1}$ We first show how the additional risk

\footnotetext{
'Throughout this paper, we examine the utility levels of various market participants and not price variability. In a paper dealing with a related issue Stein (1987) focuses on the interactions of two differentially informed types of investors, and shows how trading by investors with noisy information can reduce the welfare of other investors by
} 
from noise trading reduces the capital stock and consumption of the economy. We then show that part of that cost is borne by rational investors. Although in some interesting cases the benefits from taking advantage of noise traders outweigh the costs of the risk they add, rational investors in many cases end up worse off.

Section II of the paper sets out the model. Section III describes the effect of noise traders on capital formation, consumption, and the utility of rational investors. Section IV discusses policy interventions in a market contaminated by noise trading, and section $\mathrm{V}$ concludes.

\section{THE MODEL}

\section{Individual Choice}

As in DSSW (1987), we use an overlapping generations model with two period-lived investors. Each investor earns an exogenous labor income in the first period of his life, and invests all of it. In the second period of life, he sells all his investments and consumes the pro. ceeds, without leaving any bequests. Each period, consumption is assumed to be numeraire.

A young investor allocates his wealth between two assets. The first asset is safe bonds which are available in infinitely elastic supply, always sell for a price of one, and pay a fixed coupon r. The second asset is risky stocks. Each unit of stock carries ownership of a single unit of productive physical capital, sells for a variable price $\mathrm{p}_{\mathrm{t}}$, and pays a risky dividend:

$$
d_{t}=\delta+\varepsilon_{t}
$$

where $\delta>_{r}$ and $\varepsilon_{t}$ is normally distributed and serially uncorrelated with zero mean.

Investors maximize a mean-variance approximation to a constant relative risk aversion expected utility function, given their own perceptions of the distribution of returns on stocks and bonds:

$$
E_{t}(U)=E_{t}\left(A_{t+1}\right)-\frac{\gamma}{2 W_{t}}\left(\operatorname{Variance}\left(A_{t+1}\right)\right)
$$


where $W_{t}$ is a young investor's wealth in period $t$ and $A_{t+1}$ is the same investor's wealth in period $\mathrm{t}+1$ when he is old. Period $\mathrm{t}$ young maximize a mean-variance utility function of their perceived distribution of wealth when old with a local coefficient of absolute risk aversion equal to $\gamma / \mathrm{W}_{\mathrm{t}}$.

There are two types of investors: noise traders and rational investors. Each type has its own representative agent. Rational investors hold rational expectations and accurately perceive the distribution of retums on all investments. Noise traders accurately perceive the rate of return on bonds, but misperceive tomorrow's cum dividend price of stocks by an i.i.d. random variable: ${ }^{1}$

$$
\rho_{t}=\rho^{*}+\eta_{t}
$$

where $\eta_{t}$ is distributed $\mathrm{N}\left(0, \sigma_{\eta}^{2}\right)$.

We assume that the extent of confusion of period t young noise traders is not known to anyone until period $t$, but becomes publicly known in period $t$. The main effect of noise trader confusion is that neither rational investors nor noise traders know how confused noise traders will be tomorrow, and therefore what their demand and the resulting equilibrium price of stocks will be. Since each investor must sell all his holdings in the next period, the uncertainty about noise traders' misperceptions and demands is an important source of risk. This risk of changes of noise trader opinion-or noise trader risk-is a main driving force of our model.

The infinitely extended overlapping generations structure assures that each investor's horizon is short. No investor has any opportunity to wait until the price of stocks recovers before selling. In contrast, investors with long horizons could wait before liquidating their positions and therefore would be less concerned with resale prices. Because for them arbitrage is less risky, they could bring prices closer to fundamental values. An overlapping generations structure may be a fruitful way to model the effects on prices of a number of institutional features, such as frequent evaluations of money managers' performance, that may lead rational, long-lived market participants to care about short term rather than long term performance.

\footnotetext{
'Because all noise traders in a given generation have the same misperception, we can focus on a representative noise trader with wealth equal to total noise trader wealth. Alternatively, $p_{t}$ can be interpreted as the average misperception of noise traders.
} 


\section{The Supply of Capital}

Our assumptions on the supply of capital to which stocks are a claim follow Pagano (1987). Each share of stock carries ownership of a single unit of physical capital. This capital does not depreciate and in every period produces $d_{t}$ units of the consumption good, which are immediately paid to the shareholder as a dividend. Each period capital can be built from and melted into the consumption good by risk-neutral entrepreneurs. These entrepreneurs can exchange capital for a constant one unit of consumption for each unit of capital good. In DSSW (1987), we assumed that supplies of stocks were completely inelastic both in the short and the long run and used this simplification to solve our model. This assumption prevented noise traders from having any effect on the productivity of the economy.

Following Pagano (1987), we assume that entrepreneurs must commit to the amount of capital they will construct or dismantle in period $t$ during period $t-1$. As a result, the net capital to be added or subtracted from the total capital stock in period $t$ must be decided on prior to the revelation of period t's noise trader demands. Once period t's uncertainty is resolved, the amount of capital $\mathrm{K}_{\mathrm{t}}$ and therefore of outstanding equity cannot be adjusted. At that point, entrepreneurs sell whatever capital they have constructed at the then-prevailing price $\mathrm{p}_{\mathrm{t}}$. It is important for this model that investors are excluded from building capital and entrepreneurs are excluded from trading in stocks. Without these restrictions, there will be arbitrage opportunities across markets. If $\mathrm{p}_{t}$ is lower (higher) than $(1+\delta) /(1+r)$ entrepreneurs could borrow (lend) an amount $\mathrm{p}_{t}$ today, buy (sell) a unit of stocks, simultaneously commit to breaking down (building up) a unit of capital in period $t+1$, and realize a positive expected profit. At any price other than $(1+\delta) /(1+r)$, therefore, risk-neutral entrepreneurs' demand for stocks is unbounded if they are allowed to trade in asset markets.

The exclusion of entrepreneurs from asset markets is a device to create a perfectly elastic long-run supply of capital while keeping the algebra of the model simple. A more realistic though more complicated model would allow entrepreneurs to both build capital and trade in asset markets. We conjecture that the effects of noise trading on economic welfare that we study would also hold in such a model as long as entrepreneurs are risk averse. 
Under these assumptions, entrepreneurs supply capital in a competitive market and set the quantity of risky capital, and therefore of stocks, available each period at:

$$
K_{t}=E_{t-1}\left(\Lambda_{t}(1)\right)
$$

where $\Lambda_{t}$ is the total demand for stocks by the period t young. In equilibrium, the expected value of the risky stock price $p_{t}$ in the future must always equal to one. If the capital stock $K_{t}$ were lower than $E_{t-1}\left(\Lambda_{t}(1)\right)$, entrepreneurs could commit to adding capital at a nonnegative expected profit; if $\mathrm{K}_{\mathrm{t}}$ were higher they would commit to breaking down capital at a nonnegative expected profit. Equation (4) thus determines the competitive supply of capital.

\section{The Pricing Rule}

In this framework a closed-form solution for asset prices can be easily obtained. Letting $\lambda_{t} i_{t}$ and $\lambda^{n}{ }_{t}$ be demands for risky stocks of young rational investors and noise traders respectively, we have:

$$
\begin{aligned}
& \lambda_{t}^{i}=w_{t}^{j}\left\{\frac{E_{t}\left(d_{t+1}+p_{t+1}-(1+r) p_{t}\right.}{\gamma \sigma_{R_{t+1}}^{2}}\right\} \\
& \lambda_{t}^{n}=w_{t}^{n}\left\{\frac{E_{t}\left(d_{t+1}+p_{t+1}-(1+r) p_{t}\right.}{\gamma \sigma_{R_{t+1}}^{2}}\right\}+W_{t}^{n}\left\{\frac{\rho_{t}}{\gamma \sigma_{R_{t+1}^{2}}^{2}}\right\}
\end{aligned}
$$

The risk $\sigma^{2} R$ of the retum from holding stocks until period $t+1$ is equal to the sum of the fundamental risk $\sigma_{\varepsilon}^{2}$ of changes in the period $t+1$ dividend and noise trader-generated price risk $\sigma^{2} \pi$ corresponding to changes in the period $\mathrm{t}+1$ price:

$$
\sigma_{R_{t+1}}^{2}=\sigma_{\varepsilon}^{2}+E_{t}\left(p_{t+1}-1\right)^{2}=\sigma_{\varepsilon}^{2}+\sigma_{\pi}^{2}
$$

In equations (5) and (6), the demand for stocks is proportional to their perceived excess returns, and inversely proportional to the variance of returns. The only difference in demands between noise traders and rational investors is that because noise traders misperceive the expected retum they have an additional demand for stocks proportional to their misperception. Importantly, the variance of retums consists both of fundamental risk and of noise trader risk arising from 
uncertainty about $\rho_{t+1}$, and therefore tomorrow's equilibrium price. In fact, this model would have a non-trivial solution even if there were no fundamental risk at all (as in DSSW, 1987) and all risk came from the unpredictability of noise trader behavior. However, in that case the assumption of two period-lived investors would be critical, for if noise trading is the sole source of risk, an infinitely-lived investor would have riskless arbitrage opportunities unless the price of stock equaled its fundamental value. In the case that we focus on here, even an infinitely-lived investor faces fundamental risk that limits his willingness to bet against noise traders, and therefore the assumption of two period-lived investors is relatively innocuous.

The total demand for stocks is the sum of demands by noise traders and rational investors:

$$
\Lambda_{t}=\left(W_{t}^{i}+W_{t}^{n}\right)\left\{\frac{(1-\delta)-(1+r) p_{t}}{\gamma \sigma_{R_{t+1}}^{2}}\right\}+W_{t}^{n}\left\{\frac{\rho_{t}}{\gamma \sigma_{R_{t+1}^{2}}^{2}}\right\}
$$

Entrepreneurs supply capital to satisfy (4) with the expected demand calculated from (8):

$$
K_{t}=\left(W_{t}^{i}+W_{t}^{n}\right)\left\{\frac{\delta-r}{\gamma \sigma_{R_{t+1}^{2}}^{2}}\right\}+W_{t}^{n}\left\{\frac{\rho^{*}}{\gamma \sigma_{R_{t+1}^{2}}}\right\}
$$

Equating demand (8) and supply (9) gives the market clearing condition for the price $\mathrm{p}_{\mathrm{t}}$ of stocks, which can be solved to obtain:

$$
\mathrm{p}_{\mathrm{t}}=1+\frac{\theta \eta_{\mathrm{t}}}{1+\mathrm{r}}
$$

where:

$$
\theta=\frac{w^{n}}{w^{i}+w^{n}}
$$

is the share of noise traders' wealth in a young generation.

Equation (10) shows that the deviation of the price of stocks from its expected value is equal to the present value of today's noise traders' misperception of tomorrow's cum dividend expected price, weighted by their share of wealth. Put differently, the price today reflects noise traders' perception of the capital gain they would eam from holding stocks. Although the expected 
price in this model is constant thanks to the work of the risk-neutral builders of capital, the actual price fluctuates because at the time that noise traders' demand becomes public the stock of capital is fixed.

Taking the variance of $(10)$ yields the equilibrium variance of share prices:

$$
\sigma_{\pi}^{2}=\frac{\theta^{2} \sigma^{2}}{(1+r)^{2}}
$$

and so the total risk associated with stocks is:

$$
\sigma_{R}^{2}=\sigma_{\pi}^{2}+\sigma_{\varepsilon}^{2}=\frac{\theta^{2} \sigma_{\eta}^{2}}{(1+r)^{2}}+\sigma_{\varepsilon}^{2}
$$

where the time subscript has been dropped because risk is constant over time.

It can be shown that noise traders eam higher average rates of return on their portfolios than do rational investors if:

$$
\text { (14) } \frac{\theta \sigma^{2}}{\rho^{\star}}<\delta-r
$$

As in DSSW (1987), the presence of noise trader risk allows some investors who do not accurately perceive return distributions to eam higher expected retums.

\section{NOISE TRADING AND THE LEVEL OF ECONOMIC ACTIVITY \\ Noise Trading and the Capital Stock}

Since we have assumed that the total wealth of each young generation is the same and that shocks to noise traders' perceptions are i.i.d., equation (4) implies that the capital stock is constant. Using the demand functions evaluated at the expected price of one, and writing $\mathrm{W}=$ $W^{n}+W^{i}$ for the total endowment of the young, the equilibrium quantity of capital is: 


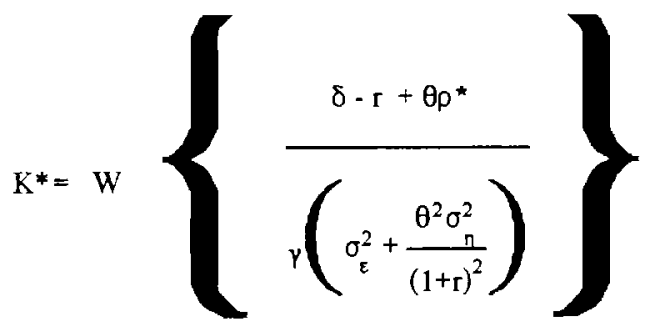

The true average return on stocks in excess of the riskless rate is $\delta-r$. Since noise traders have wealth share $\theta$ and believe that the average excess return on a unit of stocks is $\delta-r^{+} p^{*}$, the numerator of (15) is the market's average "expectation" of the excess retum. The quantity of capital is equal to this average "expectation" of the excess retum divided by the risk $\sigma_{R}{ }^{2}$ of stocks and by the market's aggregate risk aversion $\gamma / W$. Of the total wealth of the young $W$, an amount $K^{*} p_{t}$ is invested in stocks, yielding a true expected rate of retum of $\left(\delta+\left(1-p_{t}\right)\right) / p_{t}$, and an amount $W$ $\mathrm{K}^{*} \mathrm{p}_{\mathrm{t}}$ in bonds yielding the safe return $\mathrm{r}$.

The quantity of capital in the absence of noise traders is given by setting the noise trader share of wealth in (15) to zero:

$$
\bar{K}=W \frac{\delta \cdot r}{\gamma \sigma_{\varepsilon}^{2}}
$$

In the absence of noise traders, the capital stock is determined by the tradeoff between its excess retum over bonds and its fundamental risk.

There are two reasons why the capital stock absent noise traders is different from the capital stock with noise traders present. If noise traders' misperceptions are biased on average, i.e. if $\rho^{*} \neq 0$, then their demand for stocks is on average different from that of rational investors. For example, if noise traders are on average bullish they on average demand too much stock. Riskneutral entrepreneurs take account of this extra expected demand in their provision of capital and accomodate it in equilibrium. Conversely, if noise traders are on average bearish, the equilibrium capital stock is lower. If $\rho^{*}=0$ and noise traders are on average unbiased, this effect disappears.

In addition to their perceptions of excess retums, investors' demands depend on the risk bome by holding stocks. The $\theta^{2} \sigma_{\eta}^{2}$ term in the denominator of (15) captures the reduction in the 
capital stock that arises from aversion to noise trader-generated price risk. This second effect unambiguously lowers the capital stock. The second term dominates, and the capital stock is lower in the presence of noise traders, if:

$$
\frac{\rho^{\star}}{\delta-\Gamma}<\frac{\theta}{(1+r)^{2}}\left(\frac{\sigma^{2}}{\sigma_{\varepsilon}^{2}}\right)
$$

For $\rho^{*} \leq 0$, it is always the case that the presence of noise traders reduces the capital stock. Even if $\rho^{*}$ is positive, only if both the noise trader wealth share $\theta$ is small and if noise traders' opinions are not volatile relative to dividend risk (that is, $\sigma_{\eta}{ }^{2} / \sigma_{\varepsilon}{ }^{2}$ near zero) is the ratio of productive capital to wealth increased because of noise traders.

A lower capital stock implies a lower average level of consumption. Since capital gains and losses on stockholdings simply redistribute wealth from one generation to another, the average level of consumption of a generation is simply:

$$
(1+r) W+K^{*}(\delta-r)
$$

which is an increasing function of the capital stock.

\section{Who Bears the Cost of Noise Trading?}

A reduction in the average level of the capital stock and of consumption does not necessarily mean that noise traders make rational investors worse off. To establish the conditions under which rational investors' ability to exploit noise traders' mistakes is outweighed by the additional uncertainty that noise traders add, we calculate the utility levels of rational investors explicitly. Given their asset demands and the distribution of retums, the expected utility of period $t$ young rational investors is the same as they would attain with a certain wealth when old equal to:

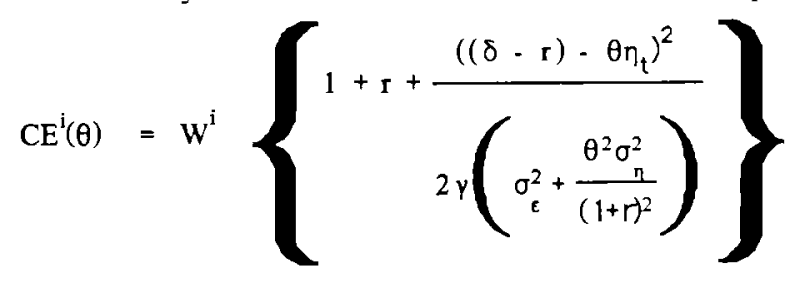


If, on the other hand, there were no noise traders in the world, the certain-equivalent wealth when old of this period $t$ young rational investor would be (20):

$$
\mathrm{CE}^{\mathrm{i}}(0)=\mathrm{W}^{\mathrm{i}}\left\{1+\mathrm{r}+\frac{(\delta-\mathrm{r})^{2}}{2 \gamma \sigma_{\varepsilon}^{2}}\right\}
$$

The difference between (19) and (20) measures the benefit (or cost) to a period $t$ young rational investor from the presence of noise traders.

It is not the case that for every generation (20) will be greater than (19). For a fixed $\theta$, for some (extreme) values of $\eta_{t}$, period $t$ young rational investors are better off with noise traders than without them, because betting against noise traders is very profitable. For moderate values of $\eta_{\mathrm{t}}$, period t young rational investors are worse off. We need a welfare index that is independent of whether a rational investor is bom into a generation with particularly crazy noise traders and is thus able to get especially rich by exploiting their misperceptions. We take as one such welfare index the expected utility of a young sophisticated investor who does not know into what generation he has been born, and is thus ignorant of the misperceptions of his noise trader contemporaries. The certain-equivalent wealth when young of such a sophisticated investor is (20) if noise traders are absent, but with noise traders present it is a random variable that is a function of $\eta_{t}$ and has an expected value of:

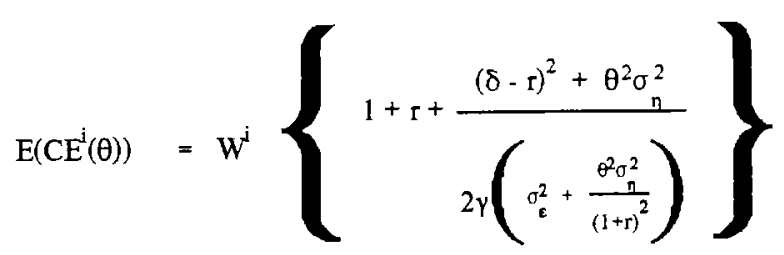

From behind the veil of ignorance, a sophisticated investor would be averse to uncertainty over the value of $\eta_{t}$ when he is young. The difference between (20) and (21) therefore understates how much a sophisticated investor behind the veil of ignorance would pay to live in a world without noise traders. A sufficient condition for the elimination of noise traders to make sophisticated investors better off in this sense is for (20) to be larger than (21). This is the case if and only if: 


$$
\frac{\delta-r}{1+r}>\sigma_{\varepsilon}
$$

When (22) holds, increases in noise trader share $\theta$ always reduce the average certain-equivalent wealth of rational investors. Since (22) is not a necessary condition, reductions in the noise trader wealth share $\theta$ might make sophisticated investors as a group better off even if (22) fails. ${ }^{1}$

The interpretation of (22) reveals two effects of a decrease in the noise trader wealth share from $\theta$ to zero. The last term in (20) and (21) reflects the value to rational investors of the ability to trade stocks. This value rises with the extra retums to productive capital $(\delta-r)^{2}$ and with returns to exploiting noise traders $\left(\theta^{2} \sigma_{\eta}{ }^{2}\right)$, and falls with additional risk of investing in stocks $\left(\gamma \sigma_{R}{ }^{2}\right)$. The presence of noise traders reduces rational investors' expected certain-equivalent wealth if the proportional increase in risk (noise trader risk and fundamental risk taken together) outweighs the proportional increase in the opportunity to exploit them. When (22) holds, extra noise trader risk at higher $\theta$ increases rational investors' risk proportionately more than it increases their opportunity. Since there is little fundamental risk compared to the magnitude of the retum premium on stocks, rational investors hold large positions. A small amount of noise trader risk has a large relative effect on the total riskiness of stocks and thus on rational investors' average holdings, but gives only a small opening for rational investors to take advantage of noise traders' mistakes. By contrast, when (22) fails rational investors' positions in the risky asset are relatively small. A rise in $\theta$ opens more opportunities for profitable trading than it closes for productive investment. ${ }^{2}$

The economy moves immediately to the new steady state in response to an unexpected shift in the noise trader wealth share $\theta$. Consider, for example, how an unanticipated elimination of noise traders from the model affects the welfare of different generations. Suppose that in generation $t$ all young investors unexpectedly tum out to be sophisticated, and it is also leamed that

\footnotetext{
${ }^{1} \mathrm{An}$ interesting property of this model is that the addition of more smart money makes current smart investors better off if (22) holds, since such an addition stabilizes prices. Contrast this with the more usual result that it is better 10 be the only smart guy around.

2Note that our model minimizes the harm done to sophisticated investors' welfare by noise traders. Since sophisticated investors know noise traders' present beliefs at all times, they exploit noise traders' misperceptions as much as possible. We conjecture that in a model in which sophisticated investors are uncertain about whether price moves are generated by fundamentals or by noise noise traders would do more damage to sophisticated investors' welfare than they do here.
} 
all future generations will be made up exclusively of sophisticated investors. Entrepreneurs in period $t$ will commit to building sufficient capital to make the period $t+1$ capital stock equal to (16), and the price in period $t$ will move to equilibrate supply and demand at the capital stock of (15) given that stocks now bear only fundamental risk. If (15) is less than (16), then the period $t$ old experience an unexpected windfall gain: they sell their capital to the young for a price greater than its ex ante expected value of one. If (22) holds, then sophisticated investors young in every period from $t$ on gain as well: the reduction in risk entailed by the elimination of noise traders more than offsets the elimination of the opportunity to exploit them.

Intuition about equations (20) and (21) can be gained by considering two extreme cases: one where $\delta=r$, and the other where $\sigma_{\varepsilon}^{2}=0$. When $\delta=r$, equation (21) becomes:

$$
E\left(C^{i}(\theta)\right)=W^{i}\left\{1+r+\frac{\theta^{2} \sigma^{2}}{2 \gamma\left(\sigma_{\varepsilon}^{2}+\frac{\theta^{2} \sigma^{2}}{(1+r)^{2}}\right)}\right\rangle
$$

Since on average stocks do not yield an excess retum, the average across generations' stock holdings of rational investors are zero. An increase in the wealth share of noise traders does not reduce rational investors' average holdings of productive capital: it simply opens up more room to exploit noise traders. When $\delta=r$, therefore, increases in the noise trader wealth share always raise the welfare of rational investors.

When $\sigma_{\varepsilon}^{2}=0$, equation ( 21$)$ becomes:

$$
\mathrm{E}\left(\mathrm{CE}^{i}(\theta)\right)=W^{i}\left\{1+r^{+} \frac{(1+r)^{2}}{2 \gamma}\left(\frac{(\delta-r)^{2}}{\theta^{2} \sigma_{\eta}^{2}}+1\right)\right\}
$$

Since noise trader risk is the sole source of risk, the average amount of certain-equivalent wealth derived from exploiting noise traders' misperceptions is constant: more noise traders means a greater average excess retum, but this is exactly offset by the greater risk that must be run. By contrast, the first term inside the parentheses, which represents the effect of noise traders on 
certain-equivalent wealth through the reduction in the capital stock caused by noise trader risk, is monotonically decreasing in $\theta$. If there is no fundamental dividend risk, then noise traders always reduce the welfare of rational investors.

\section{Noise Traders' Utility Levels}

The average certain-equivalent wealth of a young noise trader is given by:

$$
E\left(C^{n}(\theta)\right)=W^{n}\left\{1+r+\frac{(\delta-r)^{2}-p^{*^{2}+\left(\theta^{2}-1\right) \sigma_{n}^{2}}}{2 \gamma \sigma_{p}^{2}}\right\}
$$

This certain-equivalent wealth level does not correspond to noise traders' perceived expected utility at any point in time. In spite of this, a paternalistic government might wish to use (25) as a guide to policies aimed at improving the utility of noise traders as well as sophisticated investors.

The difference between (25) and (21) is the extra term $-\rho \star 2-\sigma_{\eta}^{2}$ in the numerator of (25), which captures the reduction in noise traders' expected certain-equivalent wealth arising from their misperceptions. Noise traders' utility is reduced both because they bear noise trader risk caused by uncertainty about the actions of future generations of noise traders and because their present misperceptions allow other investors to exploit them.

\section{STEPS TO REDUCE NOISE TRADER RISK}

Our model can be used to ask how asset markets could be restructured to reduce the ham done to rational investors' interests by noise traders. Ideally, one would like to find an intervention that cripples destabilizing noise while leaving untouched the ability of asset markets to fulfill their resource-allocating and liquidity-providing functions. In this section, we briefly consider three types of interventions aiming to reduce noise trader risk: stabilizing open-market operations, transaction taxes, and short-term capital gains taxes.

\section{Open-Market Operations}


The government can use open market operations to buy stocks when $\rho_{t}$ is low and sell them when $\rho_{t}$ is high. Such policies in principle could smooth out transitory, noise trader-induced fluctuations while allowing prices to adjust to persistent changes in fundamentals. In the stock market, extreme values of noise trader opinion manifest themselves in extreme price-earnings ratios, and so can be detected by authorities. Even if the govemment has no informational advantage over private speculators, it could in principle stabilize stock prices and raise the stock of capital.

In our model, open-market operations have straightforward effects. Suppose the government knows, as sophisticated investors do, that the reproduction cost of capital is one, and takes a net position:

$$
\lambda_{t}^{B}=\frac{\beta\left(1-p_{t}\right) W}{\gamma \sigma_{R}^{2}}
$$

The government buys low and sells high. Then the price of stocks in any period will be:

$$
p_{t}=1+\frac{\theta \eta_{t}}{1+r+\beta}
$$

The effect of government open-market operations on the price is thus exactly the same as the effect of reducing the noise trader wealth share from $\theta$ to:

$$
\theta^{\prime}=\left(\frac{1+r}{1+r+\beta}\right) \theta
$$

In particular, as $\beta$ rises to infinity $\theta$ ' falls to zero, and the price converges to its fundamental value one. This form of government intervention raises the ratio of "smart" to "dumb" money in the marketplace by placing the government and its wealth on the smart, stabilizing side. Since the government knows as much about the market as do the rational sophisticated investors, it can improve their welfare by entering the market on their side just as an increase in the number of sophisticated investors would increase the welfare of present sophisticated investors. The stabilizing group of sophisticated investors plus the government, with whatever additional sources 
of tax revenues the govemment can call upon, is likely to be less risk averse in the aggregate than sophisticated investors alone.

By contrast, a government that does not know for certain which price movements arise from shifts in fundamentals and which arise from shifts in noise traders' beliefs might not be able to improve welfare through open market operations. Gains in welfare from the reduction in noise would be at least partly offset by reductions arising from the govemment's erroneous neutralization of fundamental-driven price movements. If the ratio of noise-driven price movements to unrecognized fundamental-driven movements is high, the government will still be able to increase social welfare for reasons similar to those set out by Friedman (1953b). If the government is completely unable to distinguish between fundamental- and noise-driven price movements, but does know that certain types of transactions are differentially favored by noise traders, then open market operations are inappropriate and intervention, if desirable at all, should take the form of the taxes on speculative gains analyzed below.

The view that monetary authorities exist to smooth noise in asset prices has held a prominent place in the discussions of central banking at least since Bagehot (1873). Sophisticated investors in the private sector are seen as lacking the resources and the nerve to successfully counteract the large swings in demand that accompany panics (Kindleberger, 1978). ${ }^{1}$ Sometimes the argument is carried further: even in normal times there is not enough smart money to optimally stabilize financial asset prices, and smoothing bond prices becomes the rule rather than the exception (see Mankiw, Miron, and Weil, 1987). ${ }^{2}$

An example of open market operations with a very large $\beta$ is the pegging of nominal exchange rates. After WWII, academic economists could see little logic behind central bankers' revealed preference for fixed, rather than floating, rates. Economists as diverse as Friedman

\footnotetext{
IThese arguments are related to the ideas of Grossman and Miller (1988) on market liquidity, although these authors do not discuss a potential role for the government.

${ }^{2}$ Miron (1988) argues that the Federal Reserve's attempt to smooth stock prices-to moderate the stock market boom of 1928.29 by raising interest rates-may have played a proximate role in causing the Great Depression. We prefer to follow Friedman and Schwartz (1963, pp. 363-4), who suggest that it was the Federal Reserve's refusal to take steps to smooth stock prices in the 1929 decline analogous to the steps taken to smooth prices during the previcus bull market that may have played a proximate role. Friedman and Schwartz note that New York Federal Reserve Bank President Harrison wanted to lower interest rates in order to moderate the stock market decline during October 1929, but that the Board of Governors in Washington did not agree.
} 
(1953a) and Okun (1969) agreed that the Bretton Woods system was inferior to one that would allow exchange rates to move more in accord with market demand. They saw systems of flexible exchange rates as likely to lead to short-run exchange rate stability and steady long-run exchange rate drift at the difference between national inflation rates, adjusted for slow shifts in underlying comparative advantage.

From this viewpoint, the large variation in exchange rates that appeared with the breakdown of Bretton Woods came as a surprise. Attempts to understand exchange rate movements as due to shifting real or monetary fundamentals have not been successful and have led to noise trader-based interpretations of exchange rate dynamics (Frankel and Froot, 1987). The unexpectedly large volatility of exchange rates in the post-Bretton Woods period might suggest that some exchange rate volatility is the result of noise trading, and that smoothing exchange rates in an attempt to reduce noise trader risk might be beneficial.

\section{Taxes}

A second form of intervention is to impose transaction taxes, in the hope of reducing noise traders' incentives to bet on their misperceptions. In our model such taxes are unattractive, since with two-period lived investors the vast majority of trading is for life-cycle purposes. With more opportunities to trade, there might be a better argument for such taxes, but our model is unsuitable for such an analysis.

A better tax in our model is a tax on short-term capital gains. In fact, since in our model agents live for two periods and sell their assets in the second, a 100\% tax on capital gains would eliminate noise traders' incentive to speculate on their misperceptions, and would stabilize prices at the constant fundamental level.

We model a capital gains tax on "speculation" as a $1-\phi$ proportional tax on the gain between the purchase and sale prices of stocks, so that the actual net retum eamed on a unit of stocks is:

$$
\delta+\phi\left(p_{t+1}-p_{t}\right)+\varepsilon_{t+1}
$$

As long as noise traders understand that they will have to pay this tax, their perception of the 
expected net return from holding a unit of stocks is:

$$
\delta+\phi\left(p_{t+1}-p_{t}\right)+\varepsilon_{t+1}+\phi \rho_{t}
$$

Because the tax reduces after tax capital gains, asset demands are less responsive to beliefs than they are without the taxes. There still remains, however, an incentive to purchase undervalued stocks: they yield higher dividends. As a result, the tax causes actual prices to respond less to a given misperception of the before-tax return:

$$
\mathrm{p}_{\mathrm{t}}=1+\frac{\phi \theta \eta_{\mathrm{t}}}{\phi+\mathrm{r}}
$$

Consequently, the variance of returns to stocks is reduced from (13) to:

$$
\sigma_{\mathrm{R}}^{2}=\frac{\phi^{2} \theta^{2} \sigma^{2}}{(\phi+r)^{2}}+\sigma_{\varepsilon}^{2}
$$

Unless noise traders are on average very bullish-have a high value of $\rho^{*}$-an increase in the tax rate $1-\phi$ increases the value of the capital stock. The reduction in retum variance leads both noise traders and sophisticated investors to expand their aggregate holdings of capital to:

$$
K=W\left\{\frac{(\delta-r)+\phi \theta \rho^{\star}}{\gamma\left(\sigma^{2}+\frac{\phi^{2} \theta^{2} \sigma^{2}}{\left(\phi^{+}\right)^{2}}\right)}\right\}
$$

In the limit, as speculative capital gains are more nearly taxed away and $\phi \rightarrow 0$, the price of stocks approaches one and asset demand for both types of investors approach the first-best rational level:

$$
\lambda_{(\phi=0)}^{i, n}=W^{i, n}\left(\frac{(\delta-r)}{\gamma \sigma_{\varepsilon}^{2}}\right)
$$

When, as in our model, all capital gains are speculative, taxing them away completely renders speculation unprofitable after tax, and therfore brings prices to their fundamental values. When (22) holds and sophisticated investors benefit more from a reduction in the effect of noise trader risk on the desirability of fundamental investment than from an increase in the opportunity to 
exploit noise traders, then a $100 \%$ capital gains tax makes both noise traders and sophisticated investors better off than any other tax rate.

The reason that the optimal tax rate is $100 \%$ for some parameter values is precisely that in our model capital gains fulfill no allocative economic function. There is no room for productive activities that capital gains encourage such as information gathering or entrepreneurship. In practice, attempting to penalize noise trading, while leaving the returns to "productive" activities untouched by taxing short- but not long-term capital gains has a number of limitations. Traders facing this tax would sell losers and hold winners until their gains became long term. Taxes on short-term capital gains also limit the liquidity of the market as investors become locked in. If liquidity is socially valuable, such taxes would do more harm than good. For example, a reduction in trading would reduce the speed with which private information is incorporated into market prices (Kyle, 1985; Black, 1986). Moreover, the value of stocks to investors who might have a sudden demand for cash is reduced, for adverse selection re tsons stressed by Kyle (1985) and Glosten and Milgrom (1985), and for immediacy reasons stressed by Grossman and Miller (1988). As a result, such investors might stay out of the stock market, and this could result in the reduction of the capital stock.

Keynes (1936) recognized that policies crippling noise trading should be kept from reducing investment incentives when he expressed his skepticism about the utility of transaction taxes:

The spectacle of modern investment markets has sometimes moved me toward the conclusion that to make the purchase of an investment permanent ...might be a useful remedy for our contemporary evils. For this would force the investor to direct his mind to the long-term prospects and to those only. But a little consideration of this expedient brings us up against a dilemma, and shows us how the liquidity of investment markets often facilitates, though it sometimes impedes, the course of new investment. For the fact that each individual investor flatters himself that his commitment is "liquid" (though this cannot be true for all investors collectively) calms his nerves and makes him much more willing to run a risk. If individual purchases of investments were rendered illiquid, this might seriously impede new investment. ${ }^{1}$

\footnotetext{
${ }^{1}$ Keynes at least played with the idea of reducing "speculation" by making the purchase or sale of liquid assets a crime: "The only radical cure for the crises of confidence which afflict the economic life of the modern world would be to allow the individual no choice between consuming his income and ordering the production of the
} 
Addressing these issues would require a more complete analysis than our model can provide.

\section{CONCLUSION}

This paper has made two points. The first deals with the proper way to assess economic performance in models that contain noise traders: we argue that one should not necessarily count the deadweight losses that noise traders impose upon themselves as part of the social cost of noise trading. Instead, economic performance should be assessed by examining the losses that noise traders' actions impose on other investors.

The second point is that noise traders can impose substantial welfare and resource costs on other investors. Noise traders provide both an opportunity and a cost for the rest of the economy. The opportunity is that they can be exploited by skillful rational investors. The cost is that their presence creates so much risk as to render unprofitable truly productive investments that a benevolent central planner or a market without noise traders would choose to undertake. In our model the cost can readily outweigh the opportunity.

Note that in our model the welfare costs imposed by noise traders are not limited to excess variability of individuals' consumption levels about their expected values. Noise traders do make consumption more volatile than it would otherwise be. But noise trading can also reduce the average level of consumption through its effects on the level of investment and the capital stock. An economist who followed Lucas (1986) and calculated welfare losses by assessing the volatility of consumption would understate the effects of noise trading, since he would ignore its effect on the mean.

Assessing the empirical magnitude of the effects outlined in our model requires an estimate of the magnitude of noise. Point estimates in Campbell and Kyle (1988) imply that if marginal required rates of retum are five percent per year or more, then even at a ten year horizon aggregate 
stock returns may well exhibit twice as much variance as they would if driven solely by fundamentals. ${ }^{I}$ In our model a given proportional increase in variance translates into the same proportional decrease in the capital stock. If the representative investor has a horizon of ten years and if there is an elastic long-run supply of equity capital to the stock market, then noise with the variance estimated by Campbell and Kyle reduces the stock of equity capital by fifty percent.

Our results have suggested two strategies-short-term capital gains taxes and open-market operations-that would in our model reduce noise traders' effects on prices and welfare. Such policies, however, might have undesirable effects on financial markets quite aside from their effect on the vulnerability of markets to noise trading.

One point worth stressing in conclusion is that noise trading does not always damage the economy. One notable exception may occur when noise traders are on average very bullish ( $\rho^{*}$ is high), overinvest in stocks, and as a result the cost of capital is low and the quantity of capital high. If there are spillovers to other investors or to workers from a higher capital stock, noise trader foolishness will be beneficial to the economy even though it hurts the noise traders themselves. Keynes (1931) for example, believed that high investment over 1925-29 had arisen to some degree out of noise traders' overoptimism, yet he also saw the 1925-29 boom as a tremendous gain: "While some part of the investment which was going on... was doubtless ill judged and unfruitful, there can, I think, be no doubt that the world was enormously enriched by the constructions of the quinquennium from 1925 to 1929 ; its wealth expanded in those five years by as much as in any other ten or twenty years of its history.... A few more quinquennia of equal activity might, indeed, have brought us near to the economic Eldorado where all our reasonable economic needs would be satisfied."

\footnotetext{
${ }^{1}$ These point estimates are subject to very large standard errors, and vary substantially across specifications.
} 


\section{REFERENCES}

Bagehot, Walter (1873) [1978], Lombard Street (London: The Economist).

Barro, Robert (1987), "Interest Rate Smoothing” (unpublished manuscript, Harvard).

Black, Fischer (1986), "Noise," Joumal of Finance 41: 529-43.

Buffett, Warren (1985), “Up the Inefficient Market," Barron's (February 25) 40.

Campbell, John and Albert Kyle (1988), "Smart Money, Noise Trading, and Stock Price Behavior" (unpublished manuscript, Princeton).

De Long, J. Bradford, Andrei Shleifer, Lawrence H. Summers, and Robert Waldmann (1987), "Noise Trader Risk in Financial Markets" (unpublished manuscript, N.B.E.R.).

Friedman, Milton (1953a), "The Case for Flexible Exchange Rates," in Essays in Positive Economics (Chicago: University of Chicago), 157-203.

Friedman, Milton (1953b), "The Effects of Full-Employment Policy on Economic Stability: A Formal Analysis," in Essays in Positive Economics (Chicago: University of Chicago), 117-33.

Friedman, Milton and Anna J. Schwartz (1963), A Monetary History of the United States (Princeton: Princeton University).

Glosten, Lawrence and Paul Milgrom (1985), "Bid, Ask, and Transaction Prices in a Specialist Market with Heterogeneously Informed Traders," Journal of Financial Economics 14 (March): 71 100 .

Graham, Benjamin (1973), The Intelligent Investor, 4th ed. (New York: Harper and Row).

Grossman, Sanford and Merton Miller (1988), "Liquidity and Market Structure," Journal of Finance 43 (July): 617-33.

Hart, Oliver and David Kreps (1986), "Price Destabilizing Speculation," Joumal of Political Economy 94 (October): $927-52$.

Keynes, John Maynard (1931), “An Economic Analysis of Unemployment," in Collected Writings, vol. XIII (London: Macmillan, 1973), 343-67.

Keynes, John Maynard (1936), The General Theory of Employment, Interest and Money (New York: Macmillan).

Kindleberger, Charles P. (1984), A Financial History of Western Europe (London: George Allen and Unwin).

Kindleberger, Charles P. (1978), Manias, Panics, and Crashes (New York: Basic Books).

Kyle, Albert (1985), "Continuous Auctions and Insider Trading," Econometrica, 53 (November): 1315-36.

LeRoy, Stephen and Richard Porter (1981), “The Present-Value Relation: Tests Based on Implied Variance Bounds," Econometrica 49 (May): 555-74. 
Lowenstein, Louis (1988), What's Wrong with Wall Street (New York: Addison-Wesley).

Lucas, Robert (1986), Models of Business Cycles (London: Basil Blackwell).

Mankiw, N. Gregory, Jeffrey Miron, and David Weil (1987), "The Adjustment of Expectations to a Change in Regime: A Study of the Founding of the Federal Reserve," American Economic Review 77 (June): 358-74.

Miron, Jeffrey (1988), "The Federal Reserve and the Destabilization of the Post-WWI Economy," (unpublished manuscript, N.B.E.R.).

Okun, Arthur M. (1969), The Political Economy of Prosperity (Washington: Brookings).

Pagano, Marco (1987), “Stock Market Volatility and Endogenous Thinness” (unpublished manuscript, C.E.P.R.).

Roll, Richard (1984), “Orange Jujce and Weather," American Economic Review 74 (December): 861-80..

Roll, Richard (1988), "R2," Joumal of Finance 43 (July): 541-66.

Shiller, Robert (1981), "Do Stock Prices Move Too Much to Be Justified by Subsequent Changes in Dividends," American Economic Review 71: (June): 421-36.

Stein, Jeremy (1987), "Informational Externalities an ${ }^{\lambda}$ Welfare-Reducing Speculation," Journal of Political Economy 95 (December): 1123-45.

Wojnilower, Albert (1980), "The Central Role of Credit Crunches in Recent Financial History," Brookings Papers on Economic Activity 1980 (Fall): 277-326. 